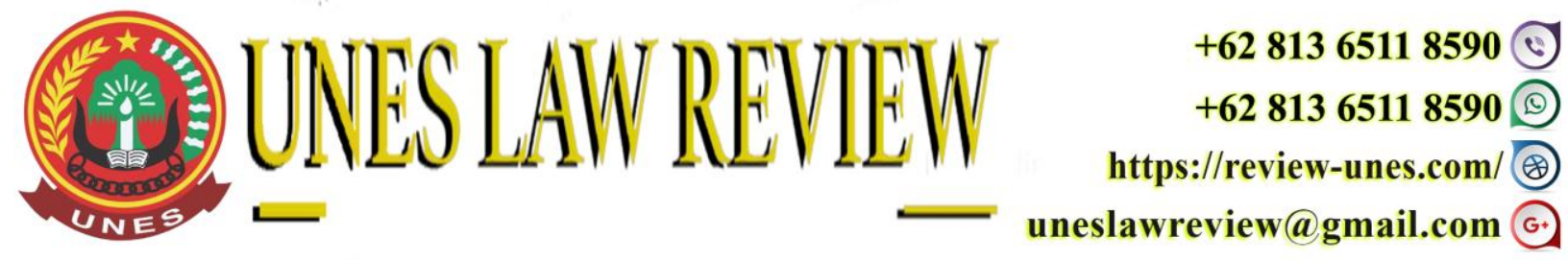

DOI: https://doi.org/10.31933/unesrev.v3i4

Diterima: 03/07/2021, Diperbaiki: 07/07/2021, Diterbitkan: 10/07/2021

\title{
PERLINDUNGAN HUKUM TERHADAP KONSUMEN DALAM PEREDARAN OBAT DAN MAKANAN TIDAK BERIZIN YANG DIPROMOSIKAN MELALUI MEDIA SOSIAL
}

\author{
Parulian Ganda Rumapea ${ }^{1}$, Charisman Jaya Zai $^{2}$, Kartina Pakpahan ${ }^{3}$, Fauzi Iansyah \\ Kantor Pertanahan Kota Padang, Indonesia \\ ${ }^{1}$ Program Studi Ilmu Hukum, Fakultas Hukum, Universitas Prima Indonesia, Indonesia \\ Email : parulian.rumapea1998@gmail.com \\ ${ }^{2}$ Program Studi Ilmu Hukum, Fakultas Hukum, Universitas Prima Indonesia, Indonesia \\ Email : charismanjayazai2017@gmail.com \\ ${ }^{3-4}$ Program Studi Ilmu Hukum, Fakultas Hukum, Universitas Prima Indonesia, Indonesia \\ Email : fauziiansyah21@gmail.com
}

Corresponding Author: Parulian Ganda Rumapea

\section{ABSTRACT}

The state has an obligation to protect, supervise every product that is circulated for consumption by the public. This study aims to identify and analyze the form of legal protection for consumers so that illegal drug and food circulation which is circulated through social media does not occur, analyze the criteria for drugs and food without a distribution permit, and forms of accountability for business actors who commit acts normative juridical research methodology using literature study. The data analysis of this research used a qualitative approach. Law Number 80 of 2017 concerning Drug and Food Control was established to protect the public against any drug product whose registration is not registered based on applicable regulations. Accountability for the distribution of illegal drugs can be subject to criminal sanctions based on Article 196 jo 197 of Law Number 30 of 2009 concerning health if it meets the elements of error and unlawful acts.

Keywords: Legal Protection, Consumer, Drug and Food Circulation, Illegal

\begin{abstract}
ABSTRAK
Negara memiliki kewajiban untuk melindungi, mengawasi setiap produk yang diedarkan untuk dikonsumsi oleh masyarakat. Penelitian ini bertujuan untuk mengidentifikasi dan menganalisis bentuk perlindungan hukum bagi konsumen agar peredaran obat dan makanan ilegal yang beredar melalui media sosial tidak terjadi, menganalisis kriteria obat dan makanan tanpa izin edar, dan bentuk pertanggungjawaban pelaku usaha. yang melakukan tindakan yuridis normatif
\end{abstract}


metodologi penelitiannya menggunakan studi kepustakaan. Analisis data penelitian ini menggunakan pendekatan kualitatif. Undang-Undang Nomor 80 Tahun 2017 tentang Pengawasan Obat dan Makanan dibentuk untuk melindungi masyarakat terhadap setiap produk obat yang pendaftarannya tidak terdaftar berdasarkan ketentuan yang berlaku. Pertanggungjawaban peredaran obat-obatan terlarang dapat dikenakan sanksi pidana berdasarkan Pasal 196 jo 197 Undang-Undang Nomor 30 Tahun 2009 tentang kesehatan apabila memenuhi unsur kesalahan dan perbuatan melawan hukum.

Kata Kunci: Perlindungan Hukum, Konsumen, Peredaran Obat dan Makanan, Ilegal

\section{PENDAHULUAN}

Kemajuan teknologi dan informasi sangat dirasakan bagi masyarakat dan mempengaruhi aktivitas didalam masyarakat. Hal ini ditandai dengan mudahnya menjalin komunikasi lintas Daerah, Nasional maupun Internasional. Mudahnya akses dan membagikan informasi melalui jejaring dan media sosial, Internet, memudahkan pemasaran barang dan jasa bagi pelaku usaha kepada konsumen. Menurut Van Dijk, jejaring sosial adalah platform komunikasi yang berfokus pada kehadiran pengguna, memfasilitasi aktivitas dan kolaborasi pengguna. Dengan cara ini, media sosial dapat dilihat sebagai media online (dukungan) yang memperkuat ikatan sosial serta hubungan antar pengguna (Rulli Nasrullah 11: 2018).

Penggunaan media sosial yang tidak tepat dapat menimbulkan masalah hukum, demikian juga pada saat pelaku usaha yang memasarkan obat dan makanan melalui media sosial yang tidak sesuai dengan peraturan perundang-undangan sehingga dikategorikan perbuatan melawan hukum, hal ini diatur dalam Pasalie9li Undang-Undangai No.i11 Tahuneo2008 Tentangie Informasiodan Transaksi Elektronik.

Produk yang diproduksi oleh produsen digunakan oleh konsumen yang secara umum dikatakan sebagai pemakai terakhir produk. Artinya, setiap orang yang mendapatkan barang untuk dipakai dan tidak untuk diperdagangkan atau diperjualbelikan lagi. Penjelasan diatas diatur didalam pasal 1 angka 2 Undang-Undang Nomor 8 Tahun 1999 tentang perlindungan konsumen bahwa konsumen adalah setiap orang pemakai barang dan /atau jasa yang tersedia dalam masyarakat, Baik bagi kepentingan diri sendiri, keluarga, orang lain, maupun makhluk hidup lain dan tidak untuk diperdagangkan (Janus Sidabalok 17:2020). Keinginan pelaku usaha untuk memperoleh keuntungan yang besar dapat menimbulkan persaingan yang tentunya mengarah pada perbuatan memproduksi obat dan makanan ilegal yang di edarkan melalui media sosial, sehingga beresiko terhadap perbuatan melawan hukum. Maka produsen bisa diminta pertangunggujawaban itu sendiri yang berkaitan dengan diteruskannya celaan objektif yang ada tindak pidana dan secara subjektif kepada seseorang yang memenuhi syarat untuk dapat dijatuhkan pidana karena perbuatannya (Dwidja Priyanto 29 : 2017).

Bentuk keberhasilan Negara Republik indonesia dalam membuat Undang-undang Nomor 11 tahun 2008 tentang Informasi dan Transaksi Elektronik (UU ITE) memberikan dua hal penting yakni (Setia Putra 291, 2014): 
1. Pengakuan transaksi elektronik dan dokumen elektronik dalam kerangka hukum perikatan dan hukum pembuktian, sehingga kepastian hukum transaksi elektronik dapat terjamin.

2. Diklasifikasikannya tindakan-tindakan yang termasuk kualifikasi pelanggaran hukum terkait penyalahgunaan TI (Teknologi Informasi) disertai dengan sanksi pidananya. Dengan adanya pengakuan terhadap transaksi elektronik dan dokumen elektronik maka setidaknya kegiatan e-commerce mempunyai basis legalnya.

Kegiatan transaksional e-commerce sudah diatur oleh Undang-Undang ITE. Namun, masih banyak kasus yang mengakibatkan konsumen masih rentan dirugikan. Faktor utama kelemahan konsumen seringkali adalah rendahnya tingkat pengetahuan hukum dan kesadaran konsumen akan hak-haknya. Kondisi ini dimanfaatkan oleh pelaku usaha untuk menghilangkan kewajiban yang harus dipenuhi kepada konsumen agar dengan mudah mencapai kepentingan mereka. Konsumen harus memiliki semua hak yang harus dilindungi. Namun, banyak konsumen yang tidak menyadari bahwa ada undang-undang yang melindungi hak-hak konsumen (Setia Putra 291, 2014).

Badan POM menggelar Konferensi pers secara virtual mengenai hasil operasi penindakan obat dan makanan diwilayah bekasi pada hari Jum'at, 25 September 2020. Penindakan ini didasarkan oleh penyelidikan secara mendalam oleh Penyidik Pegawai Negeri Sipil (PPNS) Badan POM yang bersinergi dengan Bareskrim POLRI pada hari Rabu 23 September 2020 terhadap sebuah ruko yang beralokasi di Bekasi. Dalam Penindakan tersebut PPNS Badan POM berhasil mengamankan barang bukti sebanyak 60 item (55 item obat tradisional ilegal dan 5 item pangan olahan ilegal) atau 78.412 pcs dengan perkiraan nilai keekonomian mencapai Rp 3.244.494.000,-. Selain itu PPNS Badan POM Telah memeriksa enam orang saksi dan tersangka dalam proses pegumpulan bahan keterangan (https://www.pom.go.id).

\section{METODE PENELITIAN}

Jenis penelitian menggunakan penelitan kualitatif. Merupakan kajian dari bahan dokumenter yang tertulis bisa berupa buku teks, surat kabar, majalah, surat-surat, film, catatan harian, naskah artikel, dan jenisnya, bahan juga dapat berasal dari pikiran seseorang yang tertuang didalam buku naskah-naskah yang terpubliksikan, untuk dianalisis, di interpretasikan, digali, untuk menetukan tingkat pencapaian pemahaman, digai untuk menuntukan tingkat pemahaman terhadap topik tertentu dari sebuah bahan atau teks tersebut (Wira Surjaweni 23 : 2020).

Tujuan penelitian mengetahui dan menganalisis perlindungan hukum terhadap Konsumen atas peredaran obat dan makanan ilegal melalui media social, kriteria obat dan makanan ilegal, dan pertanggungjawaban pidana kepada pelaku mengedarkan obat dan makan ilegal melalui media social. 


\section{HASIL DAN PEMBAHASAN}

\section{Upaya Perlindungan Terhadap Konsumen Atas Peredaran Obat dan Makanan Ilegal melalui Media Sosial.}

Negaraa memiliki peran untuk memajukan health sebagai salah satu upaya dalam mensejahterakan masyarakat(RizkasAnnisanIlham 9 : 2015). Dalam menghindari kerugian dari pelaku usaha, maka perlindungan konsumen digunakane untukE menggambarkanAbentuk perlindungan hukum yang diberikan kepada konsumen (Pratiwi dan Ni Kadek Diah Sri 16 : 2019). Perlindungan hukum adalah perlindungan yang diberikan oleh hukum terhadap hak dan kewajiban manusia (Gita Saraswati 5 : 2019). Hak dan kewajiban merupakan dasar adanya hubungan pelaku komersial dengan konsumen (Ali Mansyur dan Rahman 6, 2015). Sebagaimana dinyatakan dalam Pasal 4 (1) dan (3) Undang-Undang No. 8 Tahun 1999, salah satu hak konsumen adalah sebagai berikut :

1. Hak atas kenyamanan, keamanan dan keselamatan dalam mengkonsumsi barang dan / jasa;

2. Hak atas informasi yang benar, jelas dan jujur mengenai kondisi dan jaminan barang dan/atau jasa (Wahyu Simon Tampubolon 53 : 2016)

Untuk melindungi hak konsumen dari pelanggaran pelaku usaha maka dibentuk suatu aturan yang melindungi konsumen (Winda Rahmadhani 12 : 2019.). Upaya perlindungan yang diberikan kepada konsumen atas peredaran obat dan makanan yang tidak memiliki izin edar dapat di dilakukan dengan secara preventif dan represif didalam upaya penegakan aturan hukum (Anak Agung Made Yuni Noviantari 247-257 : 2021). Tindakan hukum secara preventif merupakan upaya pencegahan yang dilakukan sebelum tindak pidana itu terjadi. Sedangkan tindakan hukum secara represif merupakan upaya yang dilakukan setelah tindak pidana tersebut terjadi. Dalam hal penanggulangan terhadap beredarnya obat dan makanan ilegal yang tidak memiliki izin edar, maka, perlunya upaya perlindungan hukum. Upaya perlindungan hukum yang dapat dilakukan antara lain tersebut telah diatur dalam regulasi Undang-Undang sebagai berikut :

1. Upaya Preventif (Pencegahan)

a. Pengawasan adalah suatu kegiatan yang dilakukan untuk memastikan bahwa semua pekerjaan telah terlaksana dengan baik atau sesuai dengan apa yang telah direncanakan sebelumnya. Upaya pengawasan yang dilakukan BPOM dalam mencegah terjadinya peredaran obat dan makanan ilegal tercntum dalam Pasal 3 Peraturan Presidan No. 80 Tahun 2017 Tentang Badan Pengawasa Obat dan Makanan. Yang dimana dijleaskan bahwa :

- BPOM membuat susunan dan penetapan norma, standar, prosedur dan kriteria obat dan makanan tentang izin edar dibidang pengawasan sebelum beredar dan pengawasan selama beredar

- BPOM melakukan pelaksanan pengawasan obat dan makanan yang berkaitan dengan izin edar, sebelum beredar dan selama beredar secara berkala. Pengawasan Sebelum Beredar adalah pengawasan Obat dan Makanan sebelum beredar sebagai tindakan pencegahan 
untuk menjamin Obat dan Makanan yang beredar memenuhi standar dan persyaratan keamanan, khasiat/ manfaat, dan mutu produk yang ditetapkan. Sementara, Pengawasan Selama Beredar adalah pengawasan Obat dan Makanan selama beredar untuk memastikan Obat dan Makanan yang beredar memenuhi standar dan persyaratan keamanan, khasiat/manfaat, dan mutuproduk yang ditetapkan serta tindakan penegakan hukum.

- BPOM berkoordinasi dengan instansi pemerintah pusat dan daerah dalam melakukan pengawasan obat dan makanan khususnya mengenai izin edar, serta melakukan bimbingan teknis dan supervisi yang lebih baik dibidang obat dan makanan.

- BPOM bekerjasama dengan perangkat pemerintah untuk melakukan penyuluhan kepada masyarakat tentang danmpak dan bahaya yang ditimbulkan dari obat dan makanan yang tidak memiliki izin, dengan cara menyebarkan informasi melaui iklan atau slogan dimedia masa maupun media cetak, ataupun memberikan informai atau edukasi secara langsung kepada masyarakat melalui suatu pertemuan yang diadakan pemerintah.

2. Upaya represif (tindakan)

Upaya represif ini dilakukan berdasarkan peraturan perundang-undangna yang telah diatur khusus, terutama berkaitan dengan hukum pidana. Dalam hal ini diperlukan suatu peraturan khusus untuk melakukan tindakan represif. Beberapa peraturan khusus yang dimaksud adalah :

\begin{tabular}{|c|c|c|c|c|}
\hline Badan POM & $\begin{array}{l}\text { UU } \\
\text { Kesehatan }\end{array}$ & UUPK & $\begin{array}{l}\text { UU } \\
\text { Perdagangan }\end{array}$ & UU ITE \\
\hline $\begin{array}{l}\text { Pasal } 2 \text { Peraturan } \\
\text { Badan POM No. } \\
27 \text { Tahun } 2017 \\
\text { Tentang } \\
\text { Pendaftaran } \\
\text { Pangan Olahan }\end{array}$ & $\begin{array}{l}\text { Pasal } 106 \\
\text { UU No. } 36 \\
\text { Tahun } 2009 \\
\text { Tentang } \\
\text { kesehatan. }\end{array}$ & $\begin{array}{l}\text { Pasal } 8 \text { ayat } \\
\text { (3) UU No. } 8 \\
\text { Tahun } 1999 \\
\text { Tentang } \\
\text { Perlindungan } \\
\text { Konsumen } \\
\text { (Dian Lestari } \\
\text { Hura 5: 2016) }\end{array}$ & $\begin{array}{l}\text { Pasal } 6 r \text { dan } \\
\text { pasal } 7 \text { Ayat } \\
\text { (1) UU No. } 7 \\
\text { Tahun } 2014 \\
\text { Tentang } \\
\text { Perdagangan }\end{array}$ & $\begin{array}{l}\text { Pasal 9 Ayat } \\
\text { (1) UU No. } \\
11 \\
\text { Tahun } 2008 \\
\text { Tentang } \\
\text { Informasi dan } \\
\text { Transaksi } \\
\text { Elektronik }\end{array}$ \\
\hline
\end{tabular}

Berdasarkan ketentuan diatas, maka perlunya pengawasan yang dilakukan oleh BPOM dan stakeholder terkait seperti dengan melakukan sidak (inspeksi mendadak) secara langsung terhadap toko swalayan, supermarket, toko serba ada (department store), apotik, ataupun toko lain yang menjual obat dan makanan secara tidak langsung melalui jejaring sosial, demi menjamin kualitas dan mutu dari suatu produk yang dijual dan memastikan registrasinya telah terdaftar di Badan POM.

BadaneiPengawaseiObateudan Makanan (BPOM) merupakan Lembaga Pemerintah Non Departemen (LPND), yaitu sesuai Keputusan Presiden Republik Indonesia Nomor 103 Tahun 2001 merupakaneilembaga pemerintahalpusat yang dibentuk untuk melaksanakan tugas pemerintah tertentu darisiPresideneiserta bertanggung jawab langsung kepada presiden (FatmaiRiskanFitrianingsihDai 138 : 2019). Lembaga pemerintah yang mempunyai tugas 
dibidang obat dan makanan dalah Badan POM, terutama menangani permasalahan dalam perlindungan konsumen (Abd Aziz 197:2020).

Diharapkan agar produk yang diedarkan kepada konsumen harus dilengkapi dengan informasi benar terhadap kandungan obat, izin penjualan obat, bentuk obat, serta khasiat dan efek samping (Luh Gede Lia Muliasari 960 : 2020). Apabila terdapat kecurangan yang dilakukan oleh pelaku usaha yang berkaitan dengan mengedarkan obat dan makanan yang tidak memiliki izin edar baik secara langsung maupun tidak langsung (melaui media sosial), maka dapat diberikan sanksi pidana dan sanksi administratif berupa pencabutan izin usaha sesuai dengan peraturan Undang-Undang yang berlaku.

\section{Kriteria Obat Dan Makanan Ilegal}

Technology dapat menigkatkan kesejahteraan dan pemahaman terhadap pengetehuan yang baik, hal ini dapat kita lihat dari bentuk pembangunan dan keahlian dalam mengakses jejaring sosial dengan mudah oleh syarakat (Elina Lestari 6 : 2015). Salah satu buntuk pengaruh kemajuan teknologi yang terjadi saat ini yaitu keuntungan lebih banyak diperoleh dengan melakukan penjualan melalui jejaring sosial, dan konsumen mudah mendapatkan produk obata yang dibutuhkan (NieputueIndra8Nandayani 197 : 2020). Secara umum masyarakat cenderung ingin memperoleh suatu produk dengan cara praktisei secara Online (NixKadekeAriati 3 : 2018).

Tindakan untuk mencegah dan mengobati penyakit yang dialami manusia, pada umunya ditangani dengan mengkonsumsi obat dari resep dokter maupun yang terdapat diapotik berdasarkanii jeniseipenyakiteidaniodosisieobatuiyang ditentukan (LianisSari 2 : 2018). Maka, sediaan farmasi dipasarkan kepada masyarakat memerlukan pengawasan yang ketat, karena produk tersebut mudah dilihat dan dibeli melalui sarana online (Leli Juwanti 165 : 2018 ).

Tentunya, dalam kegiatan pelaku usaha ini sudah menjadi tanggung jawab Pemerintah dalam mengawasi setiap pendistribusian produk obat yang aman, bermutu, dan bermanfaat dalam hal menjamin mutu obat serta melindungi masyarakat dalam bentuk izin yang meliputi :

\begin{tabular}{|c|c|c|c|}
\hline & Dasat IHukum & Wewrenang & Fungsi \\
\hline $\begin{array}{c}\text { Izin Usaha } \\
\text { (IUI, TIDISIUP) }\end{array}$ & $\begin{array}{l}\text { Peraturan } \\
\text { Pemerintah Nomor } \\
107 \text { Tahun } 2015 \\
\text { tentang Izin Usaha } \\
\text { Industri. }\end{array}$ & $\begin{array}{l}\text { Kementrian } \\
\text { Perindustrian } \\
\text { atau Pemerintah } \\
\text { Provinsi/Kota } \mathbb{K} \\
\text { abupaten. }\end{array}$ & $\begin{array}{l}\text { Legalitas } \\
\text { Pendirian Industri } \\
\text { atau kegiatan } \\
\text { usaba bidang } \\
\text { produksi. } \\
\text { distributor atau } \\
\text { perdagangan. }\end{array}$ \\
\hline Izin Praduksi & $\begin{array}{l}\text { Bab III bagian kesatu } \\
\text { pasal } 6-11 \text { permenkes } \\
\mathbb{R} \text { Nomor oo6 } \\
\text { Tahun } 2012 \\
\text { Tentane Industri dan } \\
\text { Usaha obat radisinal. }\end{array}$ & $\begin{array}{l}\text { Mentri } \\
\text { kesehatan } \\
\text { dengan rekomen } \\
\text { dasi oleh Dinas } \\
\text { Kesehatan } \\
\text { Rota/Rabupaten } \\
\text { setempat. }\end{array}$ & $\begin{array}{l}\text { Tntuk melakukan } \\
\text { pengendalian } \\
\text { terhadap produksi } \\
\text { obat untuk } \\
\text { memenuhi CPIBE }\end{array}$ \\
\hline Izin EAdax & 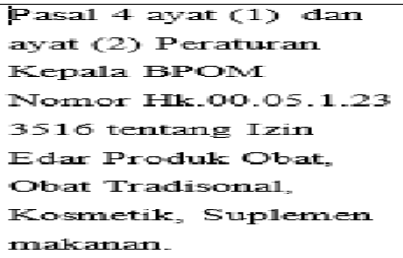 & BPONI & $\begin{array}{l}\text { Fegistrasi produk } \\
\text { kosmetik untuk } \\
\text { memastikan } \\
\text { bahwa produk } \\
\text { tersebut dapa } \\
\text { didistribusikan } \\
\text { secara legal } \\
\text { diwnillayak } \\
\text { indonesia. }\end{array}$ \\
\hline
\end{tabular}


Izin usaha merupakan persetujuan pemilik untuk melakukan kegiatan kormesial. Nama izin usaha diikuti dengan jenis usahanya, misalnya untuk obat-obatan disebut tanda daftar usaha industri farmasi. Tujuan pemberian izin usaha bidang farmasi kepada pemerintah adalah sebagai sarana untuk mengendalikan usaha penyelenggaraan agar tidak merugikan orang lain atau lingkungan. Bagi pengusaha obat izin usaha merupakan legalitas berusaha (Lilikiipudjiastutis164 : 2013).

Izin produsi adalah pemilik pabrik farmasi yang mendapat persetujuan Kementrian Kesehatan untuk melaksanakan kegatan produksi farmasi yang bertujuan untuk mengendalikan industri farmasi, sehingga produksi farmasi dapat mencapai kemanan, kepraktisan dan mutu bat obat melalui penerapan obat yang baik "Persyaratan Pratik Manufaktur (CPKB)" (Lilikiipudjiastutis164 : 2013).

Pasal 4 ayat (1) dan ayat (2) Peraturan Kepala Badan POM mengenai perizinan pemasaran diatas mencantumkan: "produk obat tradisional, kosmetik, dan supemen makanan secarar umum tidak bersifat kedaruratan." Sehingga untuk produk kosmetika yang bersumber, mengandung, atau berasal dari bahan tertentu tidak diberikan izin edar. Badan POM mempunya wewenang mengeluarkan izin edar terhadap obat yang memenuhi persyaratan, sehingga dapat digunakan dan dikonsumsi oleh masyarakat. Sebaliknya akan dkatakan ilegal jika registrasi obat belum bisa diedarkan (Syafrina Maisusri 2 : 2016).

Kriteria obat dan makanan ilegal dapat kita lihat dari bentuk perizinan yang telah diatur dalam peraturan diatas, yang dimana dalam peraturan tersebut mewajibkan setiap pelaku usaha mengikuti setiap prosedur yang telah ditentukan dalam Undang-Undang. Sebaliknya, dapat dikatakan bahwa obat dan makanan yang registrasinya tidak terdaftar kepada BPOM dan tidak memiliki izin edar tergolong Ilegal.

\section{Bentuk Pertangungg Jawaban Terhadap Pelaku Usaha Atas Peredaran Obat Dan Makanan Ilegal.}

Berdasarkan penemuan Badan POM terhadap operasi penindakan obat dan makanan di wilayah Bekasi pada hari jum'at, 25 September 2020. Ditemukan barang bukti sebanyak 60 item (55 item obat tradisional illegal dan 5 item pangan olahan ilegal) atau 78.412 pcs dengan perkiraan nilai keekonomian mencapai Rp 3.244.494.000,-. Dalam pemeriksaan itu Badan POM memeriksa enam orang saksi dan tersangka dalam proses pengumpulan bahan keterangan.

Menurut Pasal 1 angka 3 UUPK, menyebutkan bahwa Pelaku usaha adalah setiap orang perorangan atau badan usaha hukum yang didirikan dan berkedudukan atau melakukan kegiatan dalam wilayah hukum negara Republik Indonesia, baik sendiri mau pun bersama-sama melalui perjanjian menyelenggarakan kegiatan usaha dalam berbagai bidang ekonomi (Az Nasution 18 : 1995). Adanya perluasan pasar dan perdagangan bebas menimbulkan persaingan yang kuat antara pelaku usaha melakukan persaingan secara tidak jujur demi melancarkan kegiatan usahanya. Ha ini pun tentunya akan berdampak kepada konsumen dimana produk yang dijual dan diedarkan dengan harga murah namun dengan kualitasnya yang buruk dan tidak layak diedarkan. 
Terjadinya kesenjangan dari persaingan perdagangan yang tidak jujur akan membawa akibat paksa masyarakat selaku konsumen yang mendapat kerugian dan dampak buruk kesehatan bagi kehidupan mereka. Pelaku usaha yang memproduksi dan mengedarkan obat dan makanan yang tidak memiliki izin edar melalu media sosial merupakan suatu perbuatan pidana. Perbuatan tersebut tentunya akan membawa dampak kerugian bagi negara dan masyarakat sebagi konsumen.

Pertanggung jawaban pidana hanya dapat terjadi setelah sesorang melakukan tindak pidana. Pertanggung jawaban pidana dilakukan atas dasar asas hukum yang tertulis "tiada pidana tanpa kesalahan". Setiap usaha untuk memidanakan orang, baik orang perseorangan maupun korporasi, karena tindak pidana yang dilakukan orang lain tanpa terlebih dahulu ditetapkan sebagai tindak pidana dalam Undang-Undang adalah pelanggaran atas asas legalitas (Kartina Pakpahan 4 : 2020).

Asas kesalahan merupani dasar penuntutan. Artinya,l sebagai suatu perbuatan yang dilarang dapat dihukum jika terbukti melakukan kejahatan (Op-cit - Dwidja Priyanto 29 : 2017). Konsekuensi dari perbuatan yang dimaksud adalah adanya pertanggung jawaban pidana dari pelaku usaha karena tindakan tersebut merugikan orang lain (Muhyar Nugraha 3 : 2015). Oleh kaerena itu, unsur kesengajaan mengandung pengertian bahwa harus ada niat untuk menunjukan "kemauan" dan "mengetahui" sifat dan akibat hukum dari tindakan yang dilakukan (Herlina Manullang, Pasaribu 19 : 2020). Dalam bentuk kasus perdaran obat dan makanan tanpa izin edar yang telah disebutkan diatas tentunya merupakan pernuatiimelawan hukum. Yang dimana pelaku dengan sengaja tanpa terganggu jiwanya, memproduksi dan mengadarkan obat dan makanan ilegal baik secara langsung ataupun secara tidak langsung (media sosial) dalam kapasitas yang banyak.

Pasal 197 Undang-Undang Nomor 3636 Tahun 2009 Tentang Kesehatan "Setiap orang yang dengan sengaja memproduksi atau mengedarkan sediaan farmasi dan/atau lalat kesehatan yang tidak memiliki izin edar sebagaimana diamksud dalam Pasal 106 ayat (1) dipidana dengan pidana penjara paling lama 15 (lima belas) tahun dan denda paling banyak Rp 1.500.000.000,00 (Satu miliar lima ratus juta rupiah)" (Op cit - Lilik Pudjiastuti 176: 2013). Kegiatan pelaku usaha juga diatur Pasal 6 dan Pasal 7 Ayat (1) UU No. 7 Tahun 2014 Tentang Perdagangan.

Pasal 62 Undang-Undang Nomor 8 Tahun 1999 tentang perlindungan konsumen, yang menjelaskan bahwa bagi pelaku usaha yang melanggar ketentuan sebagaimana dimaksud dapat sanksi pidana berdasarkan Ketentuan Pasal 8, Pasal 9, Pasal 10, Pasal 13 ayat (2), Pasal 15, Pasal 17 ayat (1) huruf a, huruf b, huruf c, huruf e, Pasal 17 ayat (2), dan Pasal 18, yang dapat diancam pidana penjara paling lama 5 lima tahun atau denda paling banyak Rp 2.000.000.000,00 (dua miliar rupiah) (Septyani Robu Hartanty 22 : 2017).

Ketentuan Undang-Undang ITE pasal 45 Ayat (1), yang menyatakan bahwa "Setiap orang dengan sengaja dan tanpa hak menyebarkan berita bohong dan menyesatkan yang mengakibatkan kerugian konsumen dalam transaksi elektronik sebagaimana dimaksud dalam Pasal 28 ayat (1) dipidana dengan pidana penjara paling lama 6 (enam) tahun dan/atau 
denda paling banyak Rp 1.000.000.000,00 (satu miliar rupiah ) (Yustina dhian Novita 53, 2021).

Pertanggung jawaban pidana yang bersifat melawan hukum, dengan tidak ada alasan pembenaran dalam teori dualistis. Maka, pelaku usaha dapat dikenakan sanksi pidana apabila secara sah melakukan perbuatan tindak pidana sesuai ketentuan yang berlaku dalam Pasalei197 Undang-Undang Nomor 36 Tahun 2009 Tentang Kesehatan. Karena peredaran obat dan makanan tanpa izin edar dapat membahayakan kesehatan mesyarakat.

\section{PENUTUP}

Upaya Pemerintah dalam melindungi masyarakat dalam peredaran obat dan makanan ilegal, yaitu dengan membentuk Peraturan Presiden Republik Indonesia Nomor 80 Tahun 2017 Tentang Pengawasan Obat dan Makanan. Dalam perturan tersebut menjelakan kedudukann, fungsi, dan kewenangan Badan POM dalam mengawasi setiap produk yang diedarkan kepada konsumen.

Kriteria obat dan makanan ilagal berdasarkan registrasi produk yang harus terdaftar terhadap Badan POM agar memastikan bahwa produk tersebut dapat didistribusikan secara legal. Jika ada produk yang registrasinya tidak terdaftar dan tidak memiliki izin edar berdasakan peraturan yang berlaku, maka obat tersebut dikatakan produk ilegal.

Pertanggung jawaban pidana yang bersifat melawan hukum, dengan tidak ada alasan pembenaran dalam teori dualistis. Maka, pelaku usaha dapat dikenakan sanksi pidana apabila secara sah melakukan perbuatan tindak pidana sesuai ketentuan yang berlaku dalam Pasal 197 Undang-Undang Nomor 36 Tahun 2009 Tentang Kesehatan.

\section{DAFTAR PUSTAKA}

\section{Buku-buku}

Asyhadie, Zaeni, 2017 Aspek-Aspek Hukum Kesehatan DI Indonesia, Depok, PT. Raja Grafindo Persada, Depok.

Nasrullah, Rulli, 2018, Media Sosial, Simbiosa Rekatama Media, Bandung.

Agus Rusianto, 2016 , “Tindak Pidana Dan Pertanggungjawaban Pidana”, Prenada Media, Jakarta.

Pratyono, Dwidja , 2017, Sistem Pertanggung jawaban Korporasi dalam kebijakan Legislasi, PT. Kharisma Putra Utama, Depok

Surjaweni, Wira, 2020, "Metodologi Penelitian”, PT. Pusaka Baru, Yogyakarta.

Sidabalok, Janus, 2010, hukum Perlndungan Konsumen di Indonesia, PT Citra Aditya Bakti, Bandung

Wibowo, Mardian , 2018 Iklan Televisi dan Perlindungan Hukum Bagi Konsumen, cv. Mandar maju, Bandung. 


\section{Undang-Undangan}

Kitab Undang-Undang Hukum Acara Pidana

Undang-Undang Perlindungan Konsumen Nomor 8 Tahun 1999.

Undang-Udang RI Nomor 19 Tahun 2016 Tentang Perubahan Atas Undang-Undang Nomor 11 Tahun 2008 Tentang Informasi dan Transaksi Elektronik.

Undang-Undang No 36 Tahun 2009 Tentang Kesehatan

Peraturan Pemerintah No 51 Tahun 2009 Tentang Pekerjaan Kefarmasian

Undang-Undang Nomor 18 Tahun 2012 Tentang Pangan

Peraturan Presiden Republik Indonesia Nomor 80 Tahun 2017 Tentang Badan Pengawasan Obat dan Makanan.

\section{Jurnal}

Ariati, NixKadek, IuWayan. (2018). Perlindunganei Hukumi Terhadape Konsumene Dalame Melakukane TransaksixOline. Kertha Semaya, vol. 5, no. 1, hal. 3.

AnnisanIlham, Rizka. (2015). Perlindungano Hukuma Terhadape Konsumeni AtasaPenjualanuObat-Obata IlegaluSecaraiOnline. Lex Jurnalica, Vol. 1, hal. 9 Malang : Universitas Brawijaya.

Abd Aziz. (2020). Tugas dan Wewenang Badan Pengawas Obat dan Makanan (BPOM) dalam Rangka Perlindungan Konsumen, Jurnal Pemikiran dan Pembaharuan Hukum Islam, vol. 23, No. 1, hal.197.

Dai, FatmaiRiskanFitrianingsihdan Rahmdahn. (2019). Perlindungann Hukumi Bagise Konsumen Terhadapii PeredaranKosmetikaIlegal. Sains dan Humaniora "Seminar Nasional Teknologi”, hal. 138.

Hura, Dian Lestari. (2016). Perlindungan Hukum Bagi Konsumen Terhadap Makanan Olahan Yang Mengandung Bahan Berbahaya Dijawa Tengah, Diponegoro Law Jurnal, vol. 5, no. 4, hal. 5 .

Hartanty, Septyani Roby. (2017). Tanggungjawab Agen Distributor Aata Peredaran Obat Kuat Import Tanpa Izin Edar Ditinjau Dari Undang-Undang Perlindungan Konsumen. Jurnal Hukum Adigama, Vol. 2, no. 1, hal. 22 Jakarta: Universitas Taruma Negara.

Juwanti, Leli. (2018) Perlindungan Hukum Terhadap Konsumen Atas Penjualan Obat-obata Ilegal Secara Online. Niagawan, vol. 7, no. 3, hal. 165 Medan : Univesitas Negeri Medan.

Lestari, Elina . (2015). Pertanggungjawaban pidana bagi pelaku usaha yang menjual kosmetik pemutih wajah yang mengandung bahan kimia berbahaya. Jurnal Hukum, Vol. 1, hal. 6, Malang: Universitas Brawijaya.

Muliasari ,Luh Gede Lia. (2020). Perdaganganu ProdukePelangsinge TanpaiIzino EdaraSecarai Onlinei Dalam Domensix HukumoPerlindungani Konsumen. Jurnal Kertha Semaya, vol. 8, no. 6, hal. 960 . 
Maisusru, Syafrina. (2016). Penegakan Hukum Terhadap Tindak Pidana Peredaran Obat Impor Yang Tidak Memiliki Izin Edar Oleh Penyidik Pegawai Negeri Sipil Balai Besar Pengawasan Obat Dan Makanan Di Pekan Baru. JOM fakultas Hukum, vol. 3, no. 2, hal. 2.

Mansyur, Ali , dan Rahman. (2015), Penegakan Hukum Perlindungan Konsumen Sebagai Upaya Peningkatan Mutu Produksi Nasional. Jurnal Pembaharuan Hukum, Vol. 2, no. 1, hal. 6. Semarang; Unissula.

Manullang, Herlina, Pasaribu.( 2020 ). Pertanggungjawaban Pidana Korporasi. hal. 19 LPPM UHN Press, hal. 19, 2020.

Noviantari, Anak Agung Made Yuni. (2021). Perlindunganu Hukumy Terhadapr Konsumens Atase Wanprestasi PelakulPelakurUsaharOnline, jurnal kertha wicara, vol. 10, no. 4, hlm. 247-257.

Nandayani, Ni Putu Indra, dan Marwanto.(2020). Perlindungan Hukum Terhadap Konsumen Atas Produk Barang Palsu Yang Dijual Secara Ecommerce Dengan Perusahaan Luar Negeri. Jurnal Kertha Semaya, vol. 8, no. 2, hal. 197.

Nugraha, Muhyar.(2015).Pertanggungjawaban Pidana Pelaku Usaha Kecil Dan Menengah, Dalam Pelanggaran Etika Bisnis. Yustisi, vol. 1, No. 1 hlm. 3, Bogor : Universitas Ibn Khaldun : Bogor.

Novita, Yustina Dhian, dan Santoso.(2021).Urgensi Pembaharuan Regulasi Perlindungan Konsumen di Era Bisnis Digital, Jurnal Pembangunan Hukum Indonesia, vol. 3, no. 1, hal. 53 Jawa Tengah: Universitas Diponegoro.

Tampubolon, Wahyu Simon.(2016).Upaya Perlindungan Hukum Bagi Konsumen Ditinjau Dari Undang-Undang Perlindungan Konsumen, Jurnal Ilmiah “Advokasi”, Vol. 04, no. 1, hal. 53Labuhan Batu: STIH

Pakpahan, Kartina dan Leviyanti.(2020.)Pertangung jawaban Pidana Korporasi Mengerdarkan Makanan Olahan Tanpa Izin Edar. Ius Civile, vol. 4, No 1, hal. 4.

Pratiwi, NisKadekuDiaho Srix, MadexNurmawati. (2019) Perlindunganu Hukumi bagisKonsumeny Terhadapa Produku Kosmetika Impory Tanpas Izini Edara Yange DijualeSecarasOnline. Kertha Semaya, Vol. 7 no. 5, hal. 16.

Pudjiastuti, Lilik. (2013). Perizinan Sebagai InstrumenPerlindungan Hukum Dalam Peredaran Kosmetika Yang Aman Bagi Kesehatan Masyarakat. Publikasi Ilmiah, hal. 164.

Ramadhani, Winda.(2019).Perlindungan Hukum Terhadap Konsumen Pada Obat-obatan Yang Tidak Memiliki Label BPOM ( Studi Kasus Obat Zenith Carnophen ). e-journal of economic law “Transparency”, hal. 12 Medan : Universitas Sumatera Utara.

Sari, Liani.(2018).Tanggung jawab Perusahaan Farmasi Yang Dialami Konsumen Obat-Obatan Terhadap Promosi Obat Di Kota Jayapura, Legal Pluralism, vol. 8, no. 2, hal. 15.

Saraswati, Gita, Dewi. (2019). Pertanggungjawaban Pelaku Usaha Bagi Konsumen Yang Menggunakan Produk Kosmetik Ilegal Dan Berbahaya. Kertha Negara, Vol. 1, hal, 5 Bali : Universitas Udayana. 
Sari, Luh Gede Lia Mulia. (2020). Perdagangan Produk Pelangsing Tanpa Izin Edar Secara Online Dalam Domensi Hukum Perlindungan Konsumen. vol. 8, no. 6, hal. 960 Bali : Universitas Udayana.

\section{Internet}

https://www.pom.go.id/new/view/more/berita/19692/Badan-POM-Intensifkan-Penindakan-Obatdan-Makanan-Ilegal-Di-Tengah-Pandemi-COVID-19.html 